\section{Intersections}

Canadian Journal of Music

Revue canadienne de musique
Intersections CANADIAN JOURAL OF MUSIC
REVUE CANADIENEE DE MUSIOUH

\title{
How We Got into Drum Circles, and How to Get Out: De-Essentializing African Music
}

\author{
Quintina Carter-Ényì, Aaron Carter-Ényì et Kevin Nathaniel Hylton
}

Volume 39, numéro 1, 2019

Decolonizing Music Pedagogies

URI : https://id.erudit.org/iderudit/1075343ar

DOI : https://doi.org/10.7202/1075343ar

Aller au sommaire du numéro

Éditeur(s)

Canadian University Music Society / Société de musique des universités canadiennes

ISSN

1918-512X (numérique)

Découvrir la revue

Citer cet article

Carter-Ényì, Q., Carter-Ényì, A. \& Hylton, K. N. (2019). How We Got into Drum Circles, and How to Get Out: De-Essentializing African Music. Intersections, 39(1), 73-92. https://doi.org/10.7202/1075343ar
Résumé de l'article

Drums of Passion (1960), l'album iconique du percussionniste nigérian Babatunde Olátúnjí, a attiré l'attention de musiciens américains éminents, de John Coltrane à Grateful Dead, et a incité les générations subséquentes à découvrir le djembé et les polyrythmies de l'Afrique de l'Ouest. Actuellement, la prolifération dans des contextes pédagogiques de cercles de tambours djembés est inquiétante, car ces cercles sont « basés sur l'appropriation et la transformation partielle » des traditions de la percussion africaine. Notre article propose des alternatives aux cercles de djembé en reconnaissant et embrassant la mélodie africaine, en particulier les idiophones à hauteur déterminée et le répertoire choral. Nous décrivons un programme, crée par deux « Historically Black Colleges » aux États-Unis, qui aborde une représentation plus équitable et plus précise des cultures africaines grâce à la littératie technologique et une grande variété de modalités d'apprentissage. (c) Canadian University Music Society / Société de musique des universités canadiennes, 2021
Ce document est protégé par la loi sur le droit d'auteur. L'utilisation des services d'Érudit (y compris la reproduction) est assujettie à sa politique d'utilisation que vous pouvez consulter en ligne.

https://apropos.erudit.org/fr/usagers/politique-dutilisation/ 


\title{
HOW WE GOT INTO DRUM CIRCLES, AND HOW TO GET OUT: DE-ESSENTIALIZING AFRICAN MUSIC
}

\author{
Quintina Carter-Ényì, Aaron Carter-Ényì, and Kevin Nathaniel \\ Hylton
}

\section{INTRODUCTION}

Bàbátúnde Olátúnjí's 1960 album Drums of Passion caught the attention of prominent American musicians from John Coltrane to the Grateful Dead and turned on subsequent generations to West African djembe (jembe) ${ }^{1}$ drumming (and to wearing tie-dyed dashikis). In North America, drum circles are among the most common representations of African music, forming the basis for MeetUp.com and other social media groups, health and wellness retreats, and even ensembles at colleges and universities. The inclusion of predominantly djembe drum circles in the education sector is alarming because drum circles are a North American invention "based on the partial appropriation and transformation (indeed, simplification) of African-based drumming" (Charry 2005, 16). Sub-Saharan Africa encompasses roughly 1,00o ethnolinguistic cultures (Lewis et al. 2013), very few of which outside of Guinea and Mali use the djembe drum. While some culturally sensitive academic programs are offered that combine song and dance with single-membrane hand drums such as the djembe, the vast expanse of African musical traditions have still largely been ignored by such curricula. This article examines how we, in North America, got into drum circles, through appropriation in the 1960s, and suggests how to get out, by recognizing and embracing African melody, especially pitched idiophones and ensemble singing. To this end, we describe a program at two Historically Black Colleges, Morehouse and Spelman Colleges in Atlanta, that combines more equitable and accurate representation of African cultures with technological literacy and a greater range of learning modalities.

1 The djembe drum is a goblet-shaped drum found in Guinea and Mali especially, but also sold in tourist markets in Accra, Ghana, in Dakar, Senegal, and elsewhere. In traditional music and dance where the djembe is indigenous, it is used within an ensemble of other instruments to cue and accent the movement of dancers. It may also mimic vocal phrases and can be heard as "talking" to the dancers. 


\section{Drum Circles: A History and Critique}

The introduction of African music to North American schools and universities may be traced back to Bàbátúnde Olátúnjí (1927-2003) and his entrancing, rhythmic, and highly influential album, Drums of Passion (see figure 1). Olátúnjí is also the arranger (with Wendell Whalum) of "Betelehemu," a widely performed choral score, recorded by the Mormon Tabernacle Choir and released as a YouTube video (2012). Olátúnjís early initiatives in African music education, both in teaching drumming and making choral arrangements, predate the contributions of Ghanaian music educator Joseph Kwabena Nketia (1921-2019), who is more widely known within academic circles for his scholarly writings.

In 1950, Bàbátúnde Olátúnjí arrived at Morehouse College from Nigeria, funded by a Rotary Scholarship, to study political science and sociology, just a few years after Martin Luther King Jr. completed his sociology degree there. Olátúnjí was surprised to learn that his African American peers "had no concept of Africa": "They asked all kinds of questions: 'Do lions really roam the streets? Do people sleep in trees?' They even asked me if Africans had tails! They thought Africa was like the Tarzan movies. Ignorance is bliss, but it is a dangerous bliss. Africa had given so much to world culture, but they didn't know it" (Williams 2001, 14).

From this moment forward, Olátúnjí made it his mission to educate Americans, both Black and white, about Africa. He started with his peers at Morehouse, but soon branched out to the broader Atlanta community in 1953 with public performances of Nigerian music and dance. Upon graduation, Olátúnjí was committed to a career as a diplomat and attended graduate school at New York University, but he was drawn to music repeatedly. First, he formed a drum and dance troupe, then he worked with the United Nations Choir and ultimately Radio City Music Hall Orchestra, which resulted in a recording contract with Columbia Records in 1958. His debut album, Drums of Passion, reached number 13 on the Billboard charts, selling millions of copies. There had been significant efforts to introduce West African music, particularly drumming and dancing, to American audiences, most notably through the work of Asadata Dafora Horton (1890-1965), who founded the African Academy of Arts and Research in 1943 (Charry 2005, 9). ${ }^{3}$ Furthermore, African-diasporic membrane drums played a role in Latin American music-making in ethnically diverse cities such as New York. ${ }^{4}$ However, Drums of Passion reached a new and significantly larger audience, predominantly white male hippies and New Age aficionados, who connected what they heard as total rhythmic freedom on the djembe with other anarchic or avant-garde aspects of their countercultures.

2 "Composer" may be a better term, as the piece is based only loosely on melodies in the mid-twentieth-century oral tradition. The lyrics and tune were not well-known in Nigeria until being retransmitted back to Nigeria through recordings of performances posted to YouTube.

3 Also, the contributions of African-American jazz drummer Chief Bey should be noted.

4 We thank Richard Harper for sharing his experience of drum circles in the Latin community in the 1960 . 

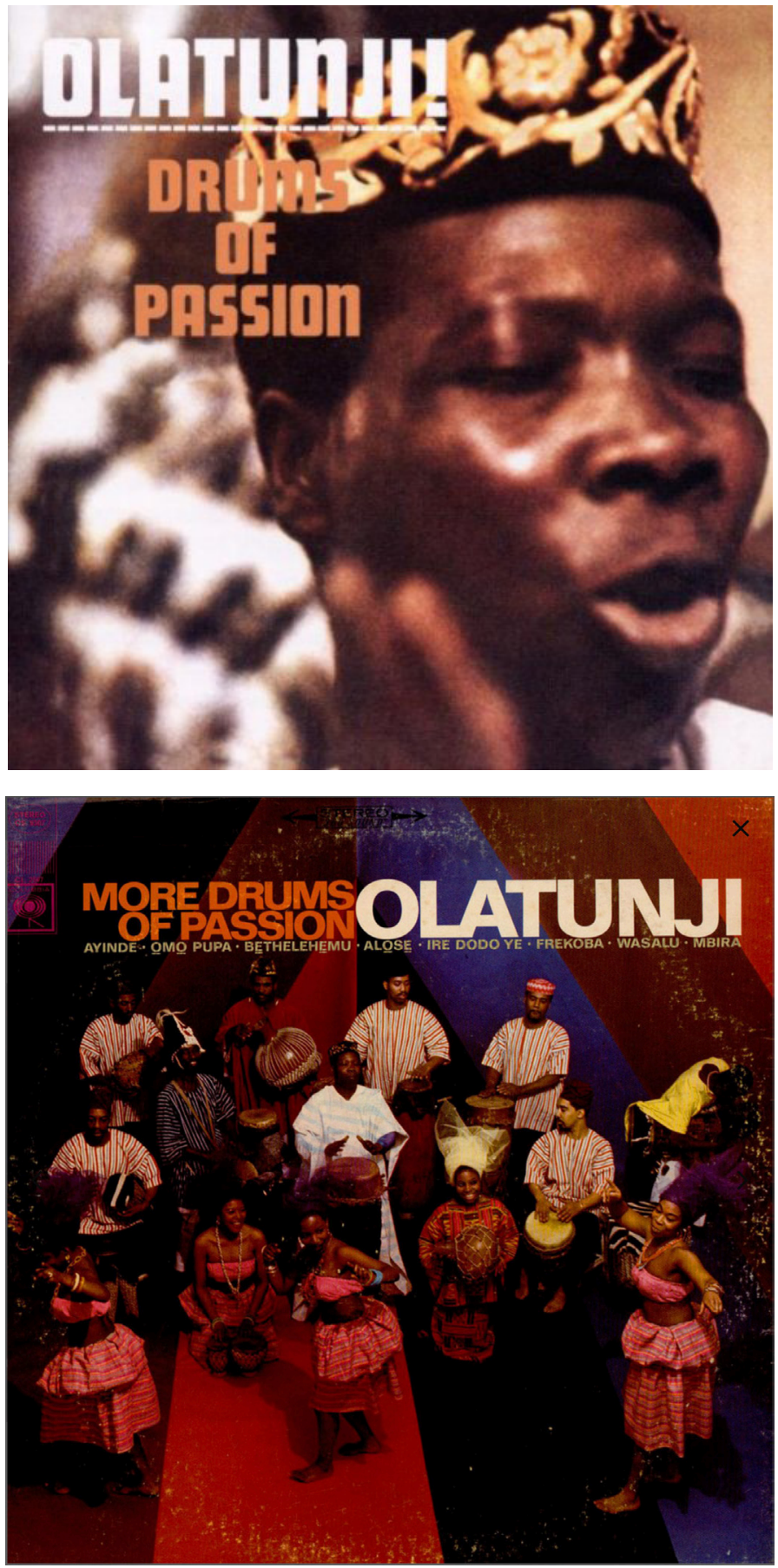

Figure 1. Album covers for Olátúnjí's Drums of Passion (1960) and More Drums of Passion (1966) 
Given Olátúnjî's "major hand" in the drum circle movement, it is ironic that Olátúnjí began his musical career in North America working to establish a group that would sing Nigerian songs. Drumming played a role as an accompaniment to singing and dancing, to complete the sound, not as the focus of the performance. As Charry points out, "It is only in the past several decades that African-based hand drumming has separated from dance and taken on a life of its own in the form of drum circles-a uniquely American development, with little African precedent ... Olátúnjí has a major hand in this movement" (Charry 2005, 14). Olátúniís aim was to connect Americans (and American music) with African heritage, exemplified by performances at the New York World's Fair and his founding of the Olátúnjí Center for African Culture in Harlem in 1965. The challenge that Olátúnjí faced was that drummers in Nigeria usually come from families or focused cultures in which they train for their entire lives to be master drum-makers and performers. In Atlanta and New York City, Olátúnjí had very little access to Nigerian drummers, so he sought out experienced hand drummers who lived in the United States. For Drums of Passion, he formed a group of some of the best percussionists of African traditions outside of Africa. When one listens to Drums of Passion, one is hearing a beautiful mashup of rhythms that span Africa and its diaspora. The mashup worked to the advantage of Drums of Passion, making it broadly accessible, but it is doubtful that Olátúnjí would have taken the same syncretic approach if a more culturally focused ensemble had been possible.

Thanks to Grateful Dead drummer Mickey Hart and another Californian, Arthur Hull, a novel experiment in popular music by Olátúnjí became an American fascination. Hart had first encountered Olátúnjí on Long Island as an elementary student in the late 1950s. Along with drum circle entrepreneur Arthur Hull, Hart became a leader in the hippie drum circle movement in Santa Cruz and San Francisco in the 1960s and 1970s. As Arthur Hull concedes, drum circles are not culturally or ethnically specific $(1998,25-6)$, and Charry similarly writes, "The very nature of the drum circle's all-inclusive philosophy (anyone can do it) precludes getting too close to African rhythms, which are typically performed in Africa by highly trained individuals (not everyone can do it)" $(2005,16)$. Hart, Hull, and other drum circle proponents since that time have drawn on two positive aspects of hand drumming in groups: inclusivity and entrainment. The inexperienced and experienced may play together. Layering patterns from simple to complex facilitates entrainment, or what Mickey Hart calls "group mind." "The Drum Circle is a huge jam session. The ultimate goal is not precise rhythmic articulation or perfection of patterned structure, but the ability to entrain and reach the state of a group mind. It is built on cooperation in the groove, but with little reference to any classic styles. So, this is a work in constant progress, a phenomenon of the new rhythm culture emerging here in the West" (Hart quoted in Charry 2005, 15).

After reconnecting with Olátúnjí in the 1980s, Hart went on to connect hand drumming with music therapy, working with Concetta Tomaino and the Institute for Music and Neurologic Function. Oliver Sacks acknowledges Hart for having "written eloquently of the power of drumming in cultures all over the 
world, and here it is especially the dynamic power of rhythm that is pre-eminent" (2006, 2528). Sacks's emphasis on the "power of drumming" and "dynamic power of rhythm" in his only reference to ostensibly African music (although effectively erased in the statement "drumming in cultures all over the world") reflects the general reductive view of African music in North America. Today, Arthur Hull is the owner and "head elf"5 of Village Music Circles, a company offering "playshops" for corporate clients around the world, including Shell Oil. ${ }^{6}$ Shell is notorious for its dealings in Nigeria (Olátúnjî's home country), such as orchestrating the execution of celebrated author and indigenous rights activist Ken Saro-Wiwa in 1995 for protesting the devastating pollution imposed on his ethnic group's home by Shell's industrial practices (Boele et al. 2001; Mouwad 2009). This interesting full circle leads back to Nigeria.

Drum circles therefore evolved with little concern for understanding or appreciating African heritage and cultures and rather focused on facilitating a visceral experience for participants. Hart and Hull's "new rhythm culture" reinforces what Nigerian novelist Chimamanda Adichie calls a "single story" about Africa (2009). Drum circles following this model demonstrate the "African rhythm" trope, which claims that African music is all about rhythm, and (an equally degrading story) that African music has no structure or complexity, so anyone can play it. Many musical cultures within Africa are indeed participatory and inclusive, but the participatory aspect is most often through responsorial singing, handclapping, and/or dancing, not haphazardly picking up an instrument that is usually played by a professional or skilled amateur. Contrary to the "African rhythm" trope, the primary component of community participation in music making - responsorial singing - is melodic as much as rhythmic.

It is not only drum circle entrepreneurs who have chosen to essentialize African music as African rhythm. The field of ethnomusicology too has at times celebrated African rhythm while largely ignoring African melody. A. M. Jones, a long-time missionary to Zambia (formerly Northern Rhodesia) coined the term "cross-rhythm" (1949). Participant-observer John Chernoff made crossrhythms and multiple meters into metaphors for Ghanaian society (1979). On the basis of fieldwork in Nigeria, Charles Keil introduced the concept of "participatory discrepancies" (1987). In theory, Keil's "participatory discrepancies" do not apply to rhythm alone, but in practice it has largely become a socio-theoretical stand-in for "polyrhythm."

\section{The Case for African Melody}

In a recent video, the African Instrumental Ensemble at the University of Nigeria Nsukka (UNN) provides an inspiring alternative example of African

5 See Hull's Village Music Circles, https://villagemusiccircles.com/product/drum-circle-spiritt-shirt/, and his LinkedIn profile, https://www.linkedin.com/in/arthur-hull-o0102714.

6 Village Music Circles, "Corporate Client List," https://villagemusiccircles.com/team-building/corporate-team-building/corporate-client-list/.

7 For more on the essentialization of African music as African rhythm, see Agawu (1995). 
music in an educational setting (African Instrumental Ensemble 2020). UNN's Department of Music largely emphasizes European classical training but also makes room for indigenous and popular styles. In this informal and largely improvised performance, a wide variety of instruments, beyond membrane drums, are used, including metal horns, pot drums, log drums, and mallet instruments. The ensemble incorporates very experienced students who have specialized on certain instruments, such as the ékwé (log drum) player, and less experienced students who sing and clap. While this particular performance is not specific to a single ethnic tradition-they are singing a Yorùbá chorus while playing a multi-ethnic assortment of instruments-this video is representative of the informal music-making to which drum circles aspire, and it incorporates melody in multiple ways.

Africana (both African and African-American) melody has often been neglected in scholarship and particularly by North American educators. Musicologist George Pullen Jackson (1874-1953) argued that "black spirituals" were derivative of "white spirituals" and conducted an early corpus study for proof. ${ }^{8}$ Mieczyslaw Kolinski (founding president of the Society for Ethnomusicology) applied contour analysis to melodies from Africa, Asia, Europe and North America. Kolinski's qualitative assessment of the "Dahomey Negro" melody (West African) was that it is "bold and ragged contrary to the smoothness of the Kwakiutl song" $(1965,116)$. The Japanese melody "smoothly swings up and down" and has a "remarkable balance in the structure of the melodic movement" (Kolinski 1965, 118).

Carter-Ényì and Carter-Ényì (2020) point out that European masterworks such as Handel's "Hallelujah Chorus" and the first movement of Beethoven's Fifth Symphony exhibit extremes of melodic angularity similar to those of the Dahomean melody. Are these melodies not also "bold and ragged"? And then there is Schoenberg, who took angularity even further. The study shows that (1) both African and European melodies may exhibit extreme angularity; and (2) the mean interval size of African-American spirituals and a well-known collection of "white spirituals," Southern Harmony, far exceed contemporary European hymnody of the nineteenth century (Carter-Ényì and Carter-Ényì 2020). Of course, both African and African-American musics have melody, but much of it is unlike the smooth stepwise motion taught in music theory courses focused on eighteenth- and nineteenth-century part-writing and counterpoint exercises-conventions that many of the "great" European classical works eschewed. Somehow melodic angularity is seen as novel and sophisticated in the music of Bach, Handel, Beethoven, and Schoenberg, but the exceptional variety of melodic invention in Africa has been swept aside-at least in how many educators still talk about African music. However, because of the profound impact of African music on North American music, and thereby global trends in popular music today, the influence of African melody is all around us and comparable to the influence of the European canon. Our curriculums

8 Tallmadge's re-analysis found only 70 of the 892 black spirituals that Jackson analyzed have melodies similar to those of white spirituals (Tallmadge 1981, 150). 
may be improved by first re-evaluating eurocentric attitudes. Once we do so, it becomes possible to see the contributions of cultures from around the world to North American musics.

\section{African Music and Dance in Higher Education}

Although early ethnomusicological scholarship contributed to the over-valuation of African rhythm compared to African melody, it is relatively rare for ensembles supported by ethnomusicology programs to adopt the Hart/Hull approach to drum circles in their curricula. Arthur Hull cites the University of California Santa Cruz as the starting point for "Village Music Circles," where he trained "7,00o students," 9 but there is no evidence that this was a formal program of the university. George Worlasi Kwasi Dor, who has directed the Ole Miss African Drum and Dance Ensemble at the University of Mississippi since 2003, has written on ethnographic study of African music and dance ensembles at several leading ethnomusicology programs (Dor 2014). He details a lesser-known stream of West African culture into North America, which also involves Olátúnjí, but started earlier, involving such figures as Asadata Dafora Horton (Sierra Leone, 1890-1965), Katherine Mary Dunham (United States, 1909-2006), and Pearl Primus (Trinidad and Tobago, 1919-94) (Dor 2014, 2932). Like Charry, Dor cites Olátúnjí's Drums of Passion as the inspiration for a large-scale movement in higher education. In contrast to the popular movement of drum circles, however, university programs have, for the most part, contextualized drumming by integrating it with ensemble singing and dancing and, in ideal programs, studying specific ethnic traditions. "Beginning in 1964 at UCLA and Columbia University, a good number of North American universities have vigorously and wholeheartedly embraced the teaching, learning, promotion, support, performance, and reception of West African dance drumming over the years ... It is no exaggeration that no less than twenty North American universities and twenty other colleges in the United States and Canada have West African drum-dance ensembles" (Dor 2014, 3).

In his book, Dor identifies and celebrates twenty-nine programs in the United States and Canada with African music and dance ensembles. Approximately a decade after Dor conducted his research, we were able to confirm through institutional webpages and/or recent YouTube videos that nineteen still have active programs that integrate song, dance, and instrument playing (see appendix). Most importantly, instrument playing is not restricted to single-membrane hand drums, but often includes pitched idiophones and shakers. Almost all of these programs are associated with a thriving ethnomusicology program and/or Africana studies program.

Many of these programs are focused on Ghanaian (usually Ashanti or Ewe) traditions. Dor confronts this by observing that Ghana is the most common national tradition represented in North American schools $(2014,6)$, but he does not advance an argument as to why, perhaps because it might cause

9 Village Music Circles, “About Arthur Hull," https://villagemusiccircles.com/about-vmc/ about-arthur-hull/. 
consternation among his Ghanaian and Nigerian colleagues who dominate English-language scholarship on West Africa. It is somewhat counterintuitive that Ghana is the focus of so much attention when the "iconic djembe" is from Mande-speaking regions (especially Guinea and Mali), not Ghana, and the most influential cultural ambassador for West African drumming, Bàbátúnde Olátúnjí, was Nigerian, not Ghanaian. Ghana has nevertheless advanced itself, particularly among English-speaking North Americans, as the leading tourist and academic exchange destination in West Africa. Much of the rest of West Africa is francophone. Because of security concerns, notoriety for corruption, and relatively expensive visas, Nigeria is not a tourist destination, despite having legendary musical cultures, both pre-colonial traditions and post-colonial innovation (such as multi-talented performer-composer Felá Kuti). In contrast, Ghana has countless programs for American college students to go to Ghana for a summer to bang on a djembe in a drum circle and wear a dashiki. Although the djembe is not central to indigenous music of major ethnic groups such as the Ashanti or Ewe, it is one of the most common items in touristy cultural markets and has been incorporated into the national tradition as practised by government-sponsored national troupes. It is the Ghanaian music of the federal institutions that is exported to North America, and the djembe is now nationally Ghanaian, although it may not be ethnically Ashanti or Ewe.

Endeavouring to be accurately pre-colonial or ethnically authentic in a university ensemble is clearly not simple and may not serve the goals of a curricular project. But if the goal is to engage in African music-making, with all of the resources now available (in a globalized and internet-connected world), it is both possible and important to try. In spite of the relative sincerity of post-secondary African ensembles outlined above, the Hart-Hullian approach of appropriation and essentialization has nevertheless entered our universities through music education (particularly in training music educators to be multicultural), music therapy, and percussion studies programs. And, perhaps less surprisingly, the drum circle's presence in general education, training in corporate team-building (in business schools), community programs, and campus ministries is more widespread. Robert Damm, a music education faculty member at Mississippi State University, has advocated recreational drum circles for general education courses as a way to have "fun in an inclusive setting ... [without] any specific musical knowledge or skills." He notes that "drum circles meet the criteria of an engaging, hands-on, experiential learning opportunity" $(2015,39)$. The issue is not that the students start without specific musical knowledge or skills, but that they may leave not only without any cultural or musical knowledge or skills, but more seriously, with the perception that they have learned "African music."

\section{Ethnic Reconnection in the United States}

Despite white nationalist movements in the United States, Canada, and Europe that remind us, sometimes violently, that racism persists, the challenges and prospects for education focused on Africana (Black) cultures are quite 


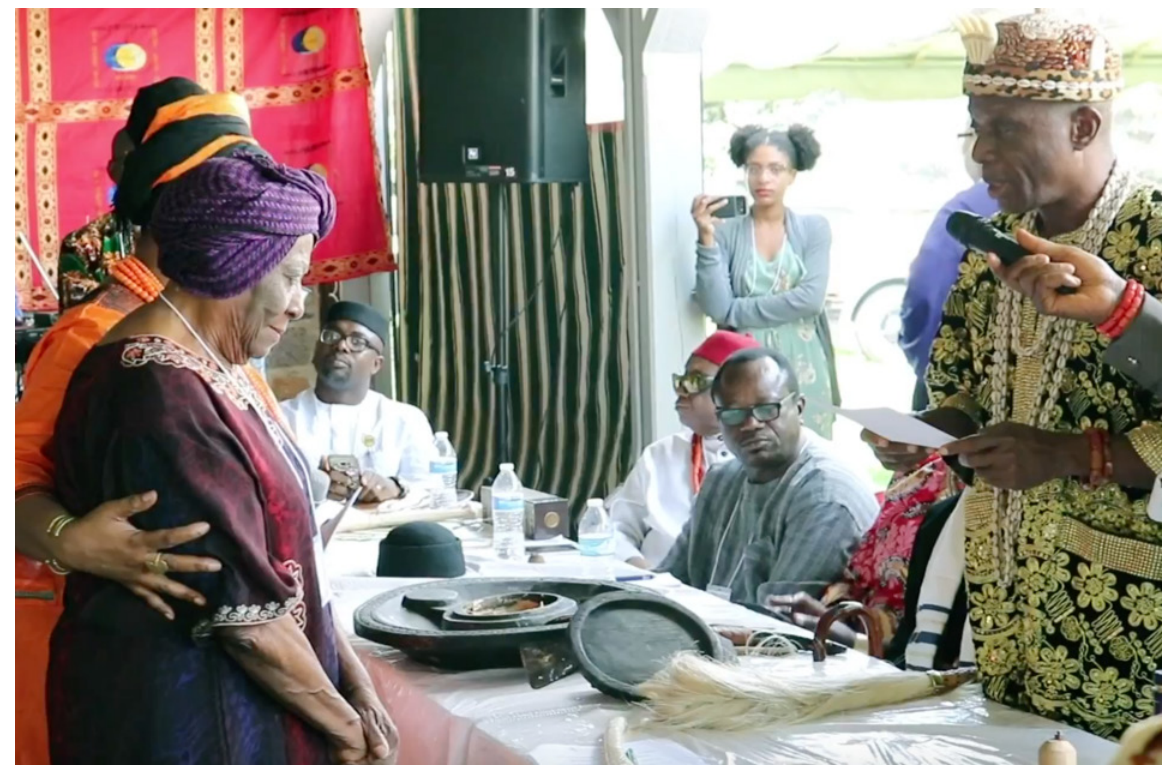

Figure 2. 2018 İgbò Reconnection Ceremony in Staunton, VA. Source: Quintina Carter-Ényì / Africana Digital Ethnography Project, https://youtu.be/IsvLekk6IEE.

different in the twenty-first century than in the 1950s and 1960s when Pan-Africanism (Black solidarity) was so essential for African independence and civil rights movements. Identity formation around ethnic heritage for African Americans has been transformed through DNA testing. An example of this move to ethnic recognition is the annual İgbò Reconnection Ceremonies in Staunton, Virginia, and Chicago, in which DNA-tested African Americans are re-initiated into the İgbò ethnic group through a naming ceremony. The event is focused on people of İgbò descent and prioritizes their reconnection, but also welcomes people not of İgbò descent, and the 2018 ceremony welcomed a young white male to the İgbò community. Thus, even white people who want to associate with Africa are being more ethnically specific instead of pan-African. Focusing on understanding and appreciating a single ethnic group avoids essentialism.

The international embrace of some specific ethnic traditions, particularly those that have contributed significantly to the globalized cultures of the Americas, bodes well for the longevity of ethnolinguistic heritage in Africa, both in its ancestral lands and abroad. The greatest concern for many of Africa's ethnolinguistic cultures in the twenty-first century is language death and the accompanying loss of musical traditions. ${ }^{10}$ Ethnically focused identity formation and cultural exploration are more consistent with Afropolitanism, a less publicly prominent but perhaps more accurate theory of the relationships between Africana cultures than Pan-Africanism (see Mbembe and Balakrishnan

10 The greatest number of human languages have been lost in the Americas, but many languages in sub-Saharan Africa are now threatened or dying. 
2016). As already noted, though ubiquitous in representations of African music in the United States, djembe is not ubiquitous in either the indigenous past or post-colonial present in the vast majority of African cultures. Choral music certainly offers a path towards Afropolitanism by enabling multi-ethnic (or even mono-ethnic) choirs to sing in many of Africa's languages. But there are also instruments that offer pan-African possibilities, such as the gourd shaker and lamellaphone, ${ }^{11}$ that are found throughout Africa and its diaspora. In addition to six regional pre-colonial traditions in sub-Saharan Africa, Kubik and Cooke note that the Kru sailors (of Sierra Leone) spread lamellaphones throughout west Africa in the nineteenth century (2001). These two instruments are also markers of the slave-trade because displaced people were able to carry them with them or make them where they landed, thus they permeate not only sub-Saharan Africa, but also the African diaspora. Offering a wider variety of music-making, in addition to dance and movement, offers much less reductive and therefore more promising opportunities for engaging with Africana cultures in university music programs.

\section{Africana Music Experiential Pedagogy}

Since 2017, we $\mathrm{e}^{12}$ have offered workshops and courses enhanced by a curriculum we call Africana Music Experiential Pedagogy (AMEP). ${ }^{13}$ AMEP emphasizes multi-sensory learning, engaging students through three pedagogical components implemented in music major and general education music courses: discussion of ethnographic primary sources; instrument making; and performance seminars. The program attempts to avoid essentialization by contextualizing Africana music in multiple ethnicities and places roughly equal emphasis on pitch and rhythm as musical features. AMEP was developed for the institutions of the Atlanta University Center (AUC), the same starting point for Olátúnjís introduction of West African drumming and Yorùbá language choral music to higher education in the United States. The program also reimagines Africa at the centre of digital innovation and music subdisciplines, like music theory, that rarely engage with Africa at all in the undergraduate curriculum. Starting in 2018, the program became the basis for outreach to many secondary school students in the Atlanta area and workshops for K-16 educators at national conferences. ${ }^{14}$

Instrument-making is an aspect of many indigenous music cultures that is often lost in non-indigenous appropriations of indigenous music-making. In many West African cultures, drum-making is taught through apprenticeship

11 Alternately spelled lamellophone.

12 Quintina Carter-Ényì and Aaron Carter-Ényì started the program in 2017. Kevin Nathaniel Hylton was a consultant in the fall of 2019.

13 AMEP has been supported by the National Science Foundation, Department of Education, and Associated Colleges of the South.

14 The Atlanta University Center (AUC) is the oldest and largest consortium of History Black Colleges and Universities in the United States. The constituent institutions are Morehouse College, Spelman College, Clark Atlanta University, and Morehouse School of Medecine. It is located in Atlanta, Georgia. 
and practised as an individual or by a small team (perhaps a family). When we were imagining how to engage students in new but culturally relevant ways, making African-centred instruments in the Morehouse Makerspace and Spelman Innovation Lab quickly arose as an avenue for maintaining that apprenticeship and team-based model, and the student response exceeded expectations. A makerspace is a trans-disciplinary space with, in this case, advanced technology like $3 \mathrm{D}$ printers and laser-cutters for physical design. When we first offered African instrument-making workshops in the Spelman Innovation Lab and Morehouse Makerspace in 2017, the response was overwhelming, with nearly two hundred participants in the first few months, most of whom had not previously visited the design prototyping labs. As of January 2020, over five hundred students had completed lamellaphones (kalimbas) and over fifty had gone onto create their own designs for culturally specific lamellaphones, created new design prototypes with faculty, or even on their own.

The core activity of AMEP is to bring students to a makerspace and immediately engage them in instrument-making. This is an approximately oneto three-hour activity that is effective for a wide variety of ages and musical experience levels, much like a drum circle, but with a much broader yield in learning. Occasionally a student's instrument does not resonate well. When this happens, we are often asked, "Why doesn't mine sound right?" in comparison to a friend's instrument. This is a teaching moment to be relished. It is when students' instrument have some fault that they really learn something. Some area, usually a corner of the resonator box, was not amply glued or fully clamped down. With a closer inspection one can locate an area where the sides are not bonded and there is usually a very small but visible gap. At this point, students are invested in the outcome and want to succeed. They are relieved when they find out that they are welcome to make another, and often do. The hardware may all be reused and the box can be repurposed as a holder for jewellery or change. For students who have only encountered factory-made instruments, this is a transformative moment.

We start with lamellaphones, but students have made many other instruments. Participants were particularly active in the fall of 2018 when they made instruments they had seen represented on African and diaspora currencies featured in a local exhibit, "Black Money," that coincided with the 2018 African Studies Association Annual Meeting being held in Atlanta.

Knowledge transfer is a core value of Africana musical cultures (including instrument-making) and of makerspaces (and hopefully higher education in general). The AMEP program started with music majors but has grown to accommodate hundreds of general education students. The music majors have become facilitators for music-making, both for general education students and for faculty and graduate students from outside the AUC. In December 2018, undergraduate students from Morehouse and Spelman offered a workshop for K-16 educators at the African Studies Association Annual Meeting. In November 2019, an even larger workshop, facilitated by eight Morehouse and Spelman music majors with over a hundred attendees, was offered for music theory faculty and graduate students at the Society for Music Theory (Carter-Ényì 2019). 


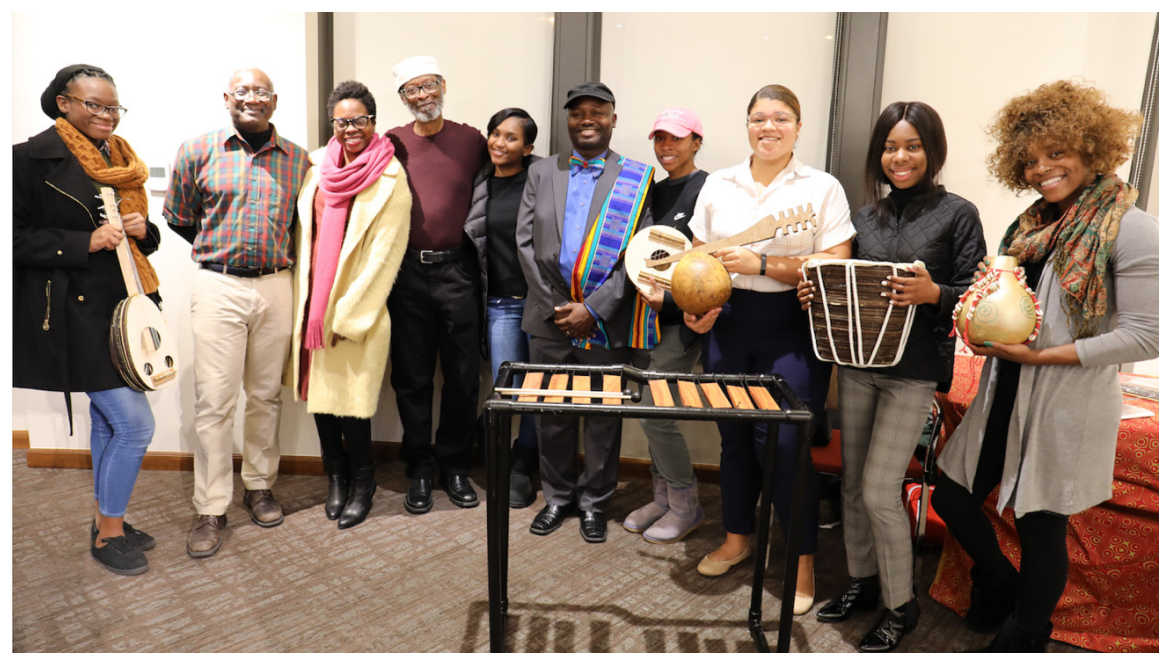

Figure 3. Spelman students and faculty with exhibit organizers at the "Black Money" exhibit, November 2018. Source: Aaron Carter-Ényì / Africana Digital Ethnography Project

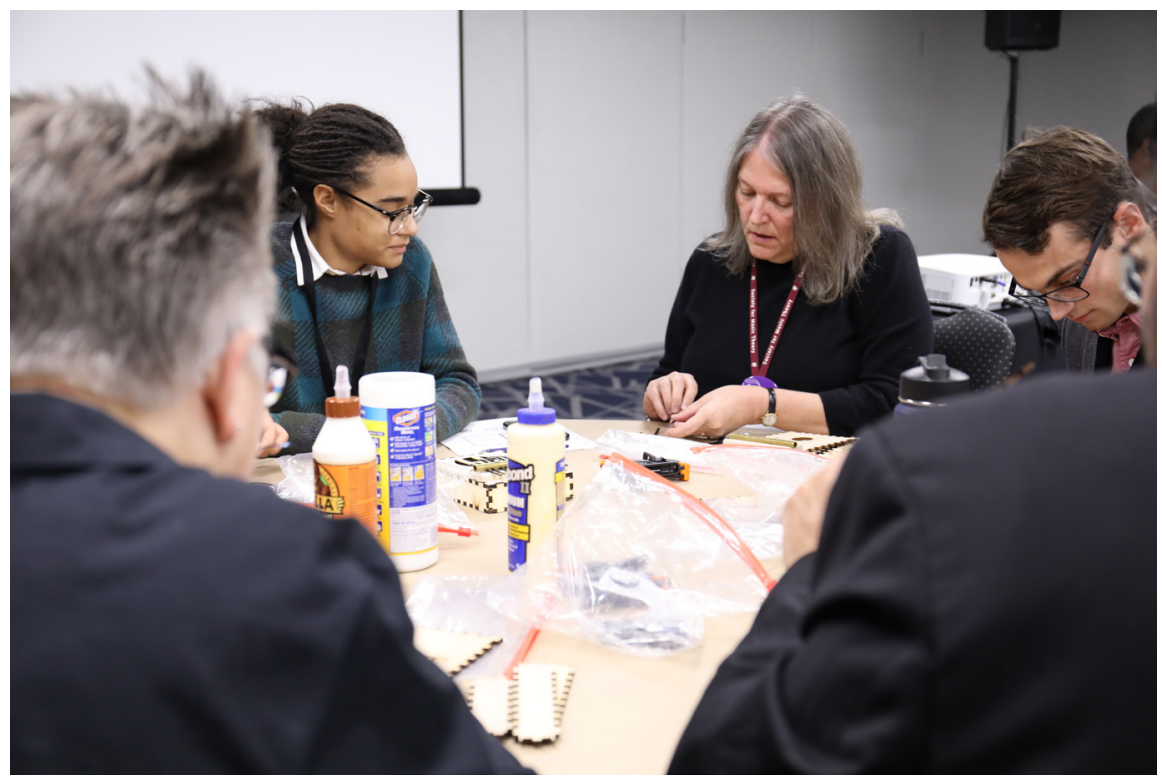

Figure 4. "Diversifying Music Theory Pedagogy" workshop at the 2019 Society for Music Theory Annual Meeting. Ariel Alvarado (Spelman music major, left) instructs conference attendees. Source: Aaron Carter-Ényì / Society for Music Theory Committee on Race and Ethnicity 
The presentation of outreach workshops is based on over two years of evaluation by participants in the AUC. Out of the 500 AUC students who have participated in kalimba workshops since 2017, we have gathered 215 sets of linked pre- and post-workshop surveys. The positive effect of the two-hour workshop was particularly strong for fine arts and humanities students, with 72 per cent reporting that it had changed their opinion of the importance of technological literacy to their career, and 75 per cent reporting that it had increased their level of interest in design and making. For those of us who know the challenges for fine arts and humanities in higher education in the United States and the necessity for digital literacy, this is an invaluable effect for a two-hour workshop.

We do not ask general education students to tune their instruments, but music majors and minors are expected to be able to tune the instrument to a variety of scales in a variety of arrangements. The first tuning students learn is a G-major pentatonic pyramidal tuning. For any music student, with the exception of players of fretless string instruments, this is a novel exercise in ear training and understanding scales.

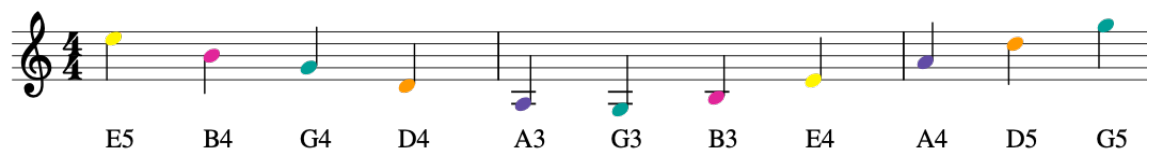

Figure 5. G-major pentatonic tuning commonly used in general education courses

We also expect advanced music theory students (juniors and seniors) to design a scale and tuning that does not have to follow equal temperament. Likewise, advanced ethnomusicology students could replicate a tuning that is culturally specific, perhaps drawing on the rich Shona tradition of mbira playing. Additionally, the instruments may be made electronic by installing a piezoelectric sensor and plugging into an amplifier. This is not only a common post-colonial phenomenon among lamellaphone players, but it also is a great experiential music technology project.

A wide variety of performance activities, both ethnically specific and eclectic, may be engaged once the instrument has been tuned and, optionally, a pickup installed. Figure 6 is an example of a duet that Quintina composed for students based on İgbò melodic and rhythmic motives. This has been used consistently with general education students, many with no prior musical training.

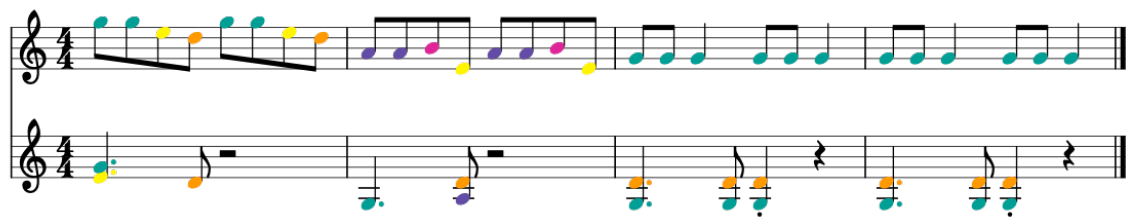

Figure 6. Ùbọ́-ákā (İgbò name for lamellaphone) duet, composed by Quintina Carter-Ényì 


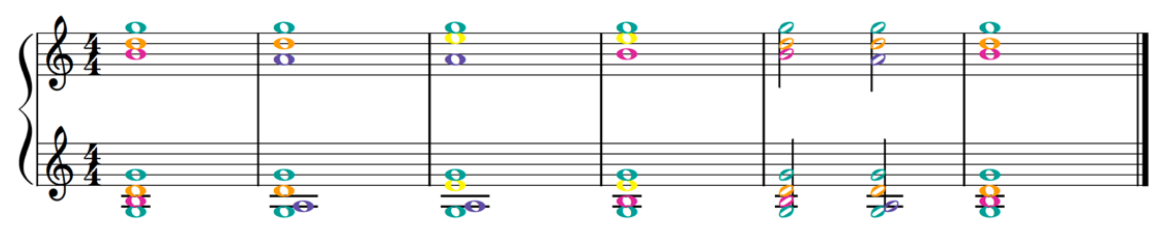

Figure 7. Colour-coded score for progression of "Lithisikiya".

Students learn to play both parts and switch during performance. The colour-coding aids students who do not know how to read Western music notation in quickly learning to play a duet. Among students who are less experienced with playing instruments, the rhythm is clearly learned aurally through rote memorization, but the learning of the pitch sequences would not be possible for many without the colour-coding.

The lamellaphone is common throughout the African diaspora, but not in North America, because U.S. slaveholders were notorious for not allowing enslaved peoples to retain any aspect of their cultures. This is in contrast to Brazil or Cuba where lamellaphones are common and languages such as Yorùbá were retained. Because many of the Morehouse general education music classes focus on African-American music, lamellaphones have also been used to learn spirituals such as "Swing Low, Sweet Chariot." Although the lamellaphone may not be traditional in nineteenth-century American performance practice, there is something profound about playing these melodies on an African-centred instrument made at Morehouse or Spelman, as opposed to a European instrument made in a factory in Asia.

In the fall of 2019, fifty general education students from Morehouse and Spelman developed kalimba parts to accompany the Morehouse College Glee Club and Afro Pop Ensemble (both comprising advanced music students) and guest musicians in a rendition of the South African anti-apartheid "Lithisikiya" ("Give me the key, open the door").

The general education students did not improvise. They were given a framework to develop a part to fit into the whole, (see Figure 7 above) much as a community music-maker in Africa knows a song and has an individual special part (maybe a vocal harmony or complementary rhythm or both) that each can add. Contrary to the jam sessions offered in drum circles, free improvisation is not actually appropriate for most ensemble music-making, in Africa or elsewhere. This classroom activity was developed into a public performance in the fall of 2019. The over one hundred students involved performed parts they developed through rehearsal, appropriate to their musical skill level. Pre-professional and professional instrumentalists trained in jazz and classical performance served as the "rhythm section" (i.e., keyboard, guitars, drum set). Five vocalists from the community and student body formed the call and the Morehouse College Glee Club learned and memorized the response. General education students, many of whom played instruments for the first time and learned through a 

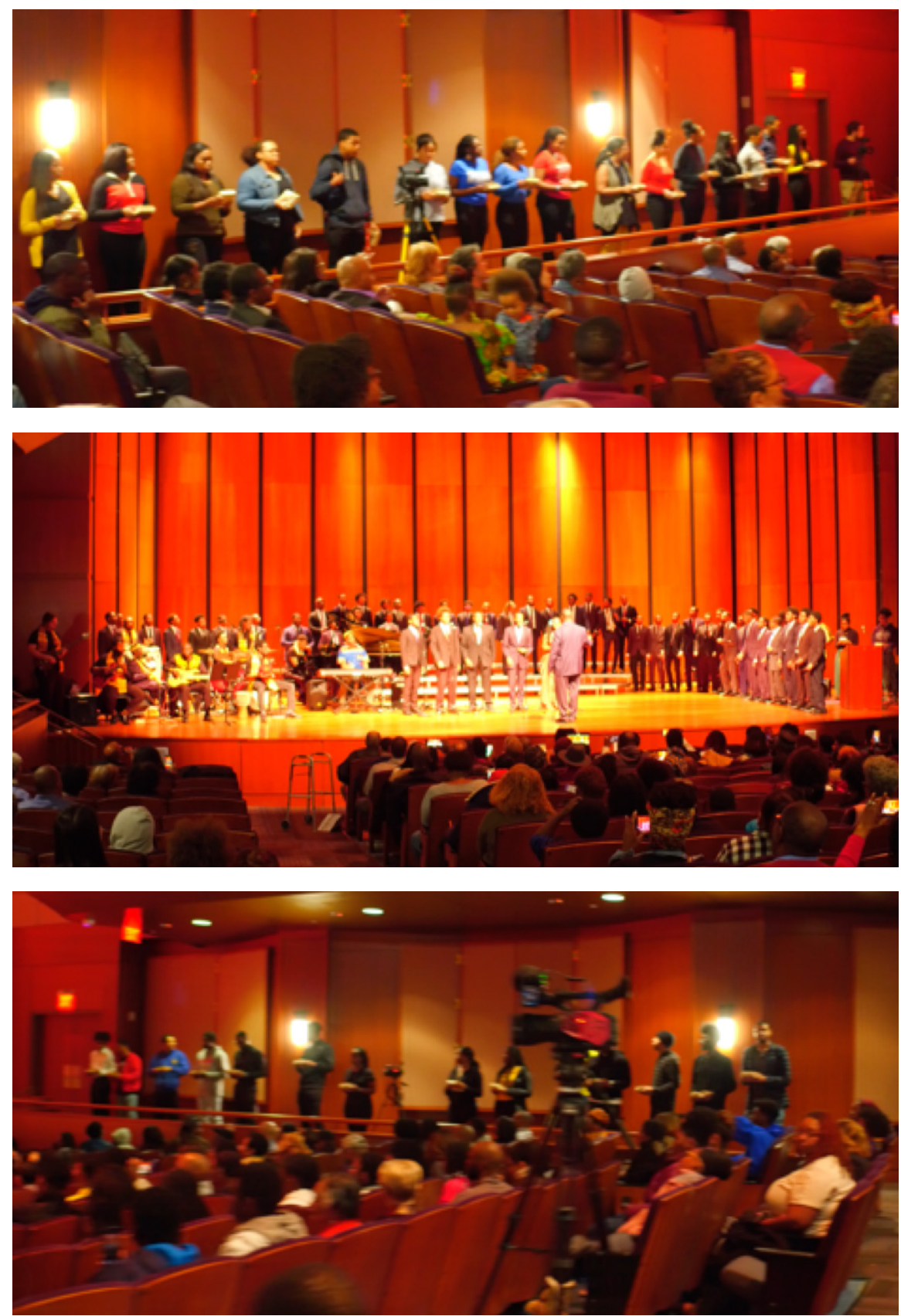

Figure 8: Africana Music Experience concert: general education students playing instruments they made (top and bottom); Morehouse Glee Club and Afro Pop Ensemble and guest artists (centre) all performing "Lithisikiya," an anti-apartheid song in three indigenous languages of South Africa: Xhosa, Zulu, and Sotho. Source: Aaron Carter-Ényì / Africana Digital Ethnography Project, https://youtu.be/76kKbGHYrUA 
combination of group and individual practice formed a kalimba "choir" that flanked the stage.

\section{Conclusion: Africana Music and Decolonial Curricular REFORM}

Learning to be an instrumentalist in Africa is done by doing. It is done not only by apprenticing in performance but also in constructing and maintaining instruments, which requires an understanding of the materials and mechanics of music (acoustics). While chronologically the hippie drum circle is a post-colonial phenomenon, it is not decolonial and could be considered neo-colonial because it is essentialist appropriation that ignores pre-colonial indigenous traditions and post-colonial African music-making.

African drum and dance groups are still a vital part of music education, and their particular value is in increasing cultural understanding, by integrating dance, song, and instrument-playing from a specific or multiple specific ethnolinguistic cultures. With AMEP, we have endeavoured to develop a program with a greater reach in student learning outcomes that is also broadly inspired by musical practices in Africa. Approaching African music from making, tuning, and a variety of playing techniques (both more and less structured) - not only free-form playing-enhances the multi-sensory aspect of learning music. To some extent, Africana Music Experiential Pedagogy also embraces the "anyone can do it" mentality of djembe drum circles and in this way is closer to drum circles than formal instruction in European or other elite musics. However, we aspire higher with the "can do" spirit and imagine African-centred education as much richer and varied than the djembe drum circle. Instrument-making is a core part of musicianship in Africa, but it is also innovative and adapts to new materials. Although AMEP uses current technology, the notion of making and playing instruments is African-centred and fundamentally decolonial. An amazing aspect of Africana musical cultures is creativity, versatility, and the ingenuity to make exceptional instruments and music with the resources available, which does not preclude the use of technology or materials that change over time.

\section{REFERENCES}

Adichie, Chimamanda Ngozi. 2009. "The Danger of a Single Story." TEDGlobal. https://www.ted.com/talks/chimamanda ngozi adichie the danger_of_a_single_story?language=en, https://ugeb.pw/id940599.pdf.

African Instrumental Ensemble. 2020. "UNN African Instrumental Ensemble Performs Nigerian Choruses." University of Nigeria Nsukka, 1 February. https://youtu.be/o3_7kS9ZlP4.

Agawu, Kofi. 1995. "The Invention of African Rhythm." Journal of the American Musicological Society 48 (3): 380-95.

- 2016. The African Imagination in Music. New York: Oxford University Press.

Boele, Richard, Heike Fabig, and David Wheeler. 2001. "Shell, Nigeria and the Ogoni. A Study in Unsustainable Development: I. The Story of Shell, 
Nigeria and the Ogoni People-Environment, Economy, Relationships: Conflict and Prospects for Resolution 1." Sustainable Development 9 (2): 74-86.

Carter-Enyi, Aaron, and Quintina Carter-Enyi. 2020. "Bold and Ragged: The Cross-Cultural Case for Melodic Angularity.” Music \& Science 3:1-14. doi: 10.1177/2059204320949065.

Carter-Enyi, Quintina. 2019. "Diversifying Music Theory Pedagogy: Instrument-Making Workshop." Society for Music Theory Annual Meeting, Columbus, $\mathrm{OH}$.

Charry, Eric. 2005. "Introduction." In The Beat of My Drum by Babatunde Olatunji. Philadelphia: Temple University Press, 1-29.

Chernoff, John Miller. 1979. African Rhythm and African Sensibility: Aesthetics and Social Action in African Musical Idioms. Chicago: University of Chicago Press.

Damm, Robert. 2015. "Recreational Drum Circles for University Students." Percussive Notes, November 2015, 38-40.

Dor, George. 2014. West African Drumming and Dance in North American Universities. Jackson, MS: University Press of Mississippi.

Hull, Arthur. 2007. Drum Circle Facilitation: Building Community through Rhythm. Milwaukee: Hal Leonard.

Jones, A. M. 1949. African Music in Northern Rhodesia and Some Other Places. Livingstone, Zambia: Rhodes-Livingstone Museum.

Keil, Charles. 1987. "Participatory Discrepancies and the Power of Music." Cultural Anthropology 2 (3): 275-83.

Kolinski, Mieczyslaw. 1965. "The Structure of Melodic Movement: A New Method of Analysis." Studies in Ethnomusicology 2:95-120.

Kubik, Gerhard, and Peter Cooke. 2001. "Lamellaphone." Grove Music Online. https://www.oxfordmusiconline.com/grovemusic/view/10.1093/ gmo/9781561592630.001.0001/omo-9781561592630-e-0000040069.

Lewis, M. Paul, Gary F. Simons, and Charles D. Fennig, eds. 2013. Ethnologue: Languages of the World. 17th ed. Dallas, TX: SIL International.

Mbembe, Achille, and Sarah Balakrishnan. 2016. "Pan-African Legacies, Afropolitan Futures.” Transition: An International Review 120 (1): 28-37.

Mormon Tabernacle Choir. 2012. "Betelehemu." YouTube. https://www.youtube.com/watch? $=$ =NggXWuqZcNw\&feature=youtu.be.

Mouawad, Jad. 2009. “Shell to Pay \$15.5 Million to Settle Nigerian Case." New York Times, 8 June.

Olátúnjí, Bàbátúnde and Robert Atkinson. 2005. The Beat of My Drum: An Autobiography. Philadelphia: Temple University Press.

Sacks, Oliver. 2006. “The Power of Music." Brain 129 (10): 2528-32.

Tallmadge, William H. 1981. "The Black in Jackson's White Spirituals." The Black Perspective in Music 9 (2): 139-60. doi: 10.2307/1214194.

Williams, B. Michael. 2001. "Bàbátúnde Olátúnjí." Percussive Notes 39 (4):14-15. 


\section{APPENDIX}

\begin{tabular}{|c|c|}
\hline Institution & Evidence that there is dance and song? \\
\hline UCLA & Ensemble is now at CalArts, not UCLA? \\
\hline $\begin{array}{l}\text { Columbia } \\
\text { University }\end{array}$ & $\begin{array}{l}\text { No longer in Music Department; Orisha Pan-African Dance Group is in Dance } \\
\text { Department }\end{array}$ \\
\hline Wesleyan & Yes \\
\hline Berkeley & Yes \\
\hline $\begin{array}{l}\text { University of } \\
\text { Toronto }\end{array}$ & $\begin{array}{l}\text { Listed on percussion site as African drumming ensemble, but an editor con- } \\
\text { firmed that it includes song and dance }\end{array}$ \\
\hline York University & Yes \\
\hline Pittsburgh & Yes \\
\hline North Texas & No dance \\
\hline West Virginia & Yes \\
\hline Florida & Yes \\
\hline Tufts & Yes \\
\hline Brown & Yes \\
\hline Ohio University & Yes \\
\hline Colorado & Highlife, not West African Drum and Dance \\
\hline MIT & Yes \\
\hline $\begin{array}{l}\text { Bowling Green } \\
\text { State }\end{array}$ & $\begin{array}{l}\text { Doesn't really seem to be West African drumming and dance, more of a calyp- } \\
\text { so band }\end{array}$ \\
\hline Illinois State & Yes \\
\hline Binghamton & Yes \\
\hline Arizona State & No dance, world percussion ensemble \\
\hline Alberta & Yes \\
\hline British Columbia & Yes \\
\hline $\begin{array}{l}\text { University of } \\
\text { Mississippi }\end{array}$ & Yes \\
\hline Oberlin & $\begin{array}{l}\text { Ended with Rod Knight's retirement, not a drum circle, no dance, an unusual } \\
\text { combination of many koras and a few other instruments }\end{array}$ \\
\hline Wabash College & Yes \\
\hline Eastman & No dance, the "iconic djembe" is the main part of the drum circle \\
\hline $\begin{array}{l}\text { University of St. } \\
\text { Thomas }\end{array}$ & Not clear that it includes dance \\
\hline Vanderbilt & Yes \\
\hline Indiana & Z162: Hand Drumming (Afro Cuban Folkloric Ensemble) \\
\hline $\begin{array}{l}\text { University of } \\
\text { Virginia }\end{array}$ & Yes \\
\hline
\end{tabular}




\section{ABSTRACT}

Babatunde Olátúnjí's Drums of Passion (1960) caught the attention of prominent American musicians from John Coltrane to the Grateful Dead and turned on subsequent generations to West African djembe drumming. The inclusion of djembe drum circles in education is alarming because they are "based on the partial appropriation and transformation" of African-based drumming. This article suggests how to get out of drum circles by recognizing and embracing African melody, especially pitched idiophones and ensemble singing. We describe a program at two Historically Black Colleges that combines more equitable and accurate representation of African cultures with technological literacy and a greater range of learning modalities.

\section{RÉSUMÉ}

Drums of Passion (1960), l'album iconique du percussionniste nigérian Babatunde Ọlátúnjí, a attiré l'attention de musiciens américains éminents, de John Coltrane à Grateful Dead, et a incité les générations subséquentes à découvrir le djembé et les polyrythmies de l'Afrique de l'Ouest. Actuellement, la prolifération dans des contextes pédagogiques de cercles de tambours djembés est inquiétante, car ces cercles sont «basés sur l'appropriation et la transformation partielle» des traditions de la percussion africaine. Notre article propose des alternatives aux cercles de djembé en reconnaissant et embrassant la mélodie africaine, en particulier les idiophones à hauteur déterminée et le répertoire choral. Nous décrivons un programme, crée par deux «Historically Black Colleges» aux États-Unis, qui aborde une représentation plus équitable et plus précise des cultures africaines grâce à la littératie technologique et une grande variété de modalités d'apprentissage.

\section{BIOGRAPHIES}

Quintina Carter-Ényì studies ethnomusicology at the University of Georgia, where she was a Georgia Innovation Now Fellow in 2018-19. She frequently offers workshops in African instrument making at colleges and universities, including Morehouse College and Spelman College, and conferences, including the African Studies Association and Society for Music Theory. Quintina sings with and directs the Morehouse Afro Pop Ensemble. Recent scholarship appears in Performance Research and Yale Journal of Music \& Religion.

Aaron Carter-Ényì is an assistant professor of music (theory) at Morehouse College, and instructor of world musics at neighbouring Spelman College. He was a Fulbright Student to Nigeria in 2013, a 2017 Fellow of the American Council of Learned Societies, and a Fulbright Scholar to Nigeria in 2019. He is the director of the interdisciplinary Africana Digital Ethnography Project and is developing the open-source software ATAVizM, both funded by the National Endowment for the Humanities.

Kevin Nathaniel Hylton graduated Yale University in 1982 as Scholar of the House. He subsequently devoted himself to music-African music in particular. He is founding member of several touring music groups including Spirit Ensemble, Heritage O P, Forestdance, Kaleidhaphonic, Africa Meets India, and Harmony Mbira. Kevin is a 
known composer of African-inspired contemporary music. He writes songs, lyrics, poetry, and essays on music and instruments. His music is available on Spotify. 